helping the primary care system rather than working in parallel or instead of it. Clear and effective coordination is required with the social and welfare services. The education and preparation of new professionals in this style of working is essential. Alternative resources for chronic and new chronic patients are needed.

To these ends, the exchange and contrast of experience is of great value, and we hope this letter is a step towards this goal.

\section{References}

MARQUINEZ, F. (1988) The reform of psychiatric services in Spain. 12th Congress of the World Association for Social Psychiatry. London, 6-10 November 1988.

INCHAUSPE, J. A. (1989) Un regard ver le Sud: La santé mentale en Espagne. L'Information Psychiatrique, May 1989, 541-542.

VARO, J. R. (1989) La atención a la Salud Mental y a las drogodependencias en Navarra. Comunidad y Drogas 13/14, 27-43. Madrid.

\title{
People and places
}

\section{Psychiatry at Keele: germination of a new department}

\author{
JoHN L. Cox, Professor of Psychiatry, University of Keele, Hartshill, \\ Stoke-on-Trent ST4 7QB
}

The 40th anniversary celebrations at Keele are proving to be a. lively acknowledgement that the University is now firmly back on its feet and has a renewed confidence in its baptismal vows. There has indeed been a recovery of Keele's raison d'être to provide multi-faculty education (all students study an arts and science subject), to pioneer a Foundation Year to allow more informed choice of Honours courses, and to accommodate undergraduates as well as many staff on its leafy 18 th century estate. The Vice Chancellor has succeeded in putting Keele back in the black, and on the map, and now plans to increase the number of students to 6,000 in the next decade.

But where, the reader may ask, does academic psychiatry and postgraduate medical education fit into this liberal-arts campus University life style? The answer goes back to the 1960 s when a strong bid for an undergraduate medical school was made but which, after several years of negotiation with the UGC, was rejected - no such new institution was to be created. There was surprise, therefore, and no doubt some hurt feelings, when a new medical school was established at Leicester which left the West Midlands with a population similar in size to Scotland having only one medical school 50 miles South in Birmingham. Nevertheless out of these ashes arose the realisation that a Postgraduate Medical School might be financed by the Health Service which would meet the need to improve local medical care and yet be consistent with Keele's particular educational ethos.

This development, therefore has come about through the farsightedness of the physicians, and of the District and Regional Health Authorities in the mid 1970s, and the need for a University Department of Postgraduate Medicine to assist in troubled financial times. This initiative was maintained by the creative attitudes of the consultants in the District General Hospital (1,000 beds) and from the consistent support of the population in North Staffordshire, who realised that money invested in medical education would improve the quality of their health care. Indeed the North Staffordshire Medical Institute, one of the largest in the country with a substantial journal library and two lecture theatres, was partially built with money from the pay packets of the potters.

How is it that psychiatry in January 1986 became among the first medical academic developments at Keele and is now one of the largest departments? Dr J. A. Hutchinson, Consultant and Clinical Tutor in North Staffordshire for 30 years and his wife Doreen, a consultant child psychiatrist, were among 
the early pioneers. They, together with Dr E. D. Myers, wished for this development and have supported it thoroughly to the present time-as have our other NHS and University colleagues in North Staffordshire, and in the West Midlands. There has remained a recognition that the NHS and the University need each other, and were therefore likely to remain entrenched for the foreseeable future.

Initially the academic psychiatrists were contained within a Department of Postgraduate Medicine but last year became a full University Department; the former Department of Postgraduate-Medicine together with Biological Sciences became a School. Other University. Departments are Medicine, Surgery, Obstetrics and Gynaecology, Traumatic Orthopaedic Surgery, Biomedical Engineering and Medical Physics; and the two Centres of Pathology and Molecular Medicine and Epidemiology/Public Health Medicine and Primary Health Care.

Psychiatry, with its roots in the biological and social sciences, seems to thrive within this multidimensional ethos of the School and University. The Department has established Senior Lecturerships in Child and Adolescent Psychiatry, Neuropsychiatry, Social Psychiatry and Mental Illness of the Elderly, and a Senior Lectureship in Liaison Psychiatry may be established shortly. There are also Lectureships in General Psychiatry and Clinical Psychology. The academic/research facilities are at present shared with other Departments within the School but the proposed new building will provide more space without losing the close links with other academics which have been the springboard for much of the development to date.

The Department is distinctive in several other respects; the University reviews each senior post after five years through external peer review, a process which encourages productivity for its own audit purposes and also reassures the NHS that their money is not being squandered. The academic consultants take their share of the on-call duties and pull their weight with clinical work; the apportionment of academic time is generally similar to UFC funded departments.

A distinctive Keele approach to psychiatric training and research is now developing; initially our academic courses were organised on traditional lines with an attempt to cover most aspects of training required for the MRCPsych examination - although initially with limited resources. The arrival of $\mathrm{Dr}$ Kenneth Barrett as Senior Lecturer enabled a more imaginative scheme to develop and this year we are offering a two-year taught MSc course in General Psychiatry and a one year Diploma suitable for General Practitioner Trainees. These courses are modular and the MSc includes a 10,000 words dissertation. They are popular with trainees on the Keele
Rotation, and also with their teachers. We include lecturers from outside the district to talk on their own specific areas of expertise; in this way students are exposed to a wide variety of teachers, and teaching techniques.

The Diploma is suitable for SHOs from other medical specialties and is the first year of the MSc course. In addition, Keele offers Masters' Degrees in Social Anthropology and Mental Handicap as well as an MSc and PhD by thesis. We are considering teaching an MSc in Clinical and Developmental Neuropsychiatry which could be particularly appropriate for Senior Registrars.

Our five year research strategy recognises the particular strengths of the University for interdisciplinary research and capitalises on the social environment of North Staffordshire, with its distinctive economic history and contrast of urban and rural environment. We make the most of academic collaboration within the Department and also with other Departments in the Medical School, such as Obstetrics and Renal Medicine. Links with other Schools and Departments in the University such as Law, Social Policy and Social Administration and Psychology also occur. We have developed further our own research interests in primary care, epidemiology of post-natal mental illness, and the social consequences of brain damage, and are investigating the impact of depression on young children.

There is therefore good reason for the University, including the academic psychiatrists, to celebrate a 40th anniversary; there is a renaissance of a belief in cross-disciplinary academic enterprise and an educational philosophy which fits well with the comprehensive training necessary for a general psychiatrist. A multi-model approach to patient care can generate productive research, although this may be more difficult to organise successfully than a more narrowly focused research activity. However, we intend to contribute distinctively to our Region and also to academic psychiatry within the UK. We recognise that the extent to which these aspirations are fulfilled can only be ascertained in future years - perhaps not until the University celebrates a 50th anniversary. By then the NHS as we know it may be unrecognisable and the tasks of a psychiatrist become more varied and community orientated. Nevertheless a well trained general psychiatrist in the year 2000 is likely to be more highly valued rather than less as the NHS, and the universities, become preoccupied with consumer choice and with the quality of care.

The Keele motto "Thanke God For All" therefore has a surprising relevance even in a secular age, and symbolises aspects of a multi-model developmental psychiatry which could partially explain how a new department has successfully germinated in the potters' clay of North Staffordshire. 